<014> DATE-OF-RECORD-ENTRY

$<015>$ DATE-RECEIVED

$<016>$ COPIES-RECEIVED

$<020>$ DOCUMENT-TYPE

$<022>$ MEDIUM-CODE

$<030>$ CIASSIFICATION-CODE

<050> GPO-SUPERINTENDENT-OF-DOCUMENTS

<072> PERSONAL-AUTHOR-AND-AFFILIATION

$<080>$ SPONSORING-ORGANIZATION-CODE

$<110>$ TITLE-ENGLISH

- Evolving microstructure: Mechanisms of copper films

<150> PRIMARY-REPORT-NIMBER

$<240>$ CONTRACT-NUMBER-DOE

<241> ABBREV-CONTRACT-NUMBER-DOE

$<242>$ AWARD ING-OFEICE-CODE

<243> BUDGET-REPORTING-CODE

$<246>$ DOE-INITIATING-OFFICE-CODE

$<247>$ MICROFICHE-DISTRIBUTION-CODE

$<248>$ VENDOR-ID-CODE

$<249>$ VENDOR-NAME

<251> REPORTING-REOUIREMENT

$<276>$ DUPCHECK-BYPASS-FTAG

<291> PACKED-PRIMARY-REPORT-NUMBER

$<293>$ PREFIX

$<295>$ INDEX-DOCUMENT-NUMBER

$<370>$ PUBIICATION-DATE

<376> REPORT-TYPE-CODE-AND-FREQUENCY

$<390>$ PAGES-BIBIIOGRAPHIC

$<400>$ REPORT-DISTRIBUTION-CODE

$<421>$ LANGUAGE-CODE

$<425>$ AUDIENCE-CODE

<426> LIMITATION-CODE

$<510>$ DISTRIBUTION-CATEGORY

$<520>$ PROJECT-STATUS

$<530>$ ANNOUNCEMENT-CODE

$<540>$ EDB-SUBJECT-CATEGORIES

$<550>$ SOURCE-OF-BIBLIOGRAPHIC-INPUT

$<560>$ COUNTRY-OF-INTELIECTUAL-ORIGIN

$<570>$ COUNTRY-OF-PUBLICATION

$<686>$ DOCUMENT-STATUS-CODE

$<700>$ CORPORATE-CODE

$<801>$ SUBJECT-DESCRIPTORS

ELECTROPHORESIS:T;MASS TRANSFER;MICROSTRUCTURE: $Q 1,02,03$; GRAIN BOUNDARIES; INTEGRATED CIRCUITS:T4; COPPER:T1; FILMS; ALUMINIUM ALIOYS:T2; COPPER ALLOYS:T3;STRESSES;MATERIALS:Q4

<931> AVAIIABILITY-CODE

<950> ABSTRACT

We report on a collective body of work wherein we have studied the mass transport phenomena which are likely to be operative during stress driven changes in microstructure arising from electromigration and stress voiding. Our goal is to understand such microstructural evolution leading to failure of the metal ines or interconnects associated with integrated electronic circuits or chips. This work, when complete, will lead to improved electronics performance and reliability and faster product development arising from accurate and predictive models of wearout phenomena. We report on the role of thermal induced strain leading to hole and hillock formation, the influence of grains structure on the reliability of Al-based interconnects, and the observation of counter-current electromigration of Ua in Al grain boundaries. 
UCRL-ID-124556

\section{Evolving Microstructure: Mechanisms of Electromigration in Stressed Aluminum-Copper and Copper Films}

\author{
M. Fluss \\ F. Génin \\ C. Kim
}

J. W. Morris, Jr.
PECEMPD

JUL 221398

OSTI

This paper was prepared for submittal to LDRD Office

in Livermore, CA, on June 24, 1996

This is an informal report intended primarily for internal or limited extemal distribution. The opinions and conclusions stated are those of the author and may or may not be those of the Laboratory.

Work performed under the auspices of the Department of Energy by the Lawrence Livermore National Laboratory under Contract W-7405-Eng-48. 


\section{DISCLAMMER}

This document was prepared as an account of work sponsored by an agency of the United States Government. Neither the United States Covernment nor the University of California nor any of their employees, makes any warranty, express or implied, or assumes any legal liability or responsibility for the accuracy, completeness, or usefulness of any information, apparatus, product, or process disclosed, or represents that its use would not infringe privately owned rights. Reference herein to any specific commercial product, process, or service by trade name, trademark, manufacturer, or otherwise, does not necessarily constitute or imply its endorsement, recommendation, or favoring by the United States Government or the University of California. The views and opinions of authors expressed herein do not necessarily state or reflect those of the United States Government or the University of California, and shall not be used for advertising or product endorsement purposes. 


\section{DISCLAIMER}

Portions of this document may be illegible in electronic image products. Images are produced from the best available original document. 


\section{Evolving Microstructure: Mechanisms of Electromigration in Stressed Aluminum-Copper and Copper Films}

FINAL REPORT for LDRD 94-ERD-019

M. Fluss, F. Génin, C. Kim, and J.W. Morris, Jr.

\begin{abstract}
We report on a collective body of work wherein we have studied the mass transport phenomena which are likely to be operative during stress driven changes in microstructure arising from electromigration and stress voiding. Our goal is to understand such microstructural evolution leading to failure of the metal lines or interconnects associated with integrated electronic circuits or chips. This work, when complete, will lead to improved electronics performance and reliability and faster product development arising from accurate and predictive models of wearout phenomena. We report on the role of thermal induced strain leading to hole and hillock formation, the influence of grain structure on the reliability of Al-based interconnects, and the observation of counter-current electromigration of $\mathrm{Au}$ in Al grain boundaries.
\end{abstract}

\section{BACKGROUND}

The fundamental issue within the reliability community is the absence of software tools that can simulate basic materials degradation mechanisms. This limitation will be overcome through a series of fundamental experiments leading to accurate and predictive models and simulations. Our efforts are focused on generating such data and at the same time to consider the possibility of discovering new alloy compositions which are likely to dramatically extend user life. To be of practical engineering use, materials efforts such as ours must focus on descriptions of phenomena that are more or less easily described by a phenomenological approach while being refined from first principles methods. We expect our efforts to inspire new, sounder constitutive models for general use among the community.

\section{STRESS-INDUCED MASS TRANSPORT}

A stress applied to the grain boundary (GB) produces an exchange of atoms between the free surface of the film and the regions where the stress is at an extreme. When a film is bounded to its substrate, these regions of high biaxial stress are located at the film-substrate interface. Both compressive and tensile stress can be understood based on the same set of mass transport equations. Compression leads to the growth of hillocks and tension to the growth of holes. In both cases mass transport proceeds through a combination of surface diffusion and grain boundary transport with the flux constant's sign depending on the sign of the stressor. The details of this work are described elsewhere ${ }^{1}$ and the references therein. In addition to developing this phenomenological model we have tested and validated it through experiments that carefully map the topography of hillocks via scanning force microscopy ${ }^{2}$.

\section{GRAIN STRUCTURE}

As the dimensions of interconnects decreases to line widths of less than one micron the grain boundary structure is

1 MRS Symp Proc. April 1995 San Francisco CA 389 p83-94

2 J. Appl. Phys. 79 (5), 1 March 1996 
observed to transition from one of polycrystalline lines to a bamboo structure where the grain boundaries are perpendicular to the flow of electrical current and hence terminate at the encapsulating interfaces. In the case where there is a mixture of ploy- and bamboo structures one observes flux divergence since grain boundary diffusion is impossible for the bamboo structure. The complex set of mass transport variables were explored in experiments on $\mathrm{Al}$ and $\mathrm{Al}$ $-2 w t . \% \mathrm{Cu}-1 w t . \% S i$ lines. The grain structures of fine lines were controlled by annealing after patterning to promote the formation of bamboo structures. For mixed bamboo structures with polygranular segments less than 5 microns significant improvement in mean time to failure and a narrowing of the failure distribution were observed compared to the as patterned lines. Void failure mechanisms at the upstream ends of the polygranular regions such as slits and voids across the bamboo grains appear to be the dominant failure mechanism and likely result from consequences of flux divergence. This work is described in more detail elsewhere. ${ }^{3}$

\section{TERNARY ALLOYS}

Because of the complex interplay among solute, solvent, impurities and other alloy components we decided to explore an alloy phase space using Edisonian techniques and some materials insights. Our goal was to enhance electromigration resistance by either finding a substitute for $\mathrm{Cu}$ which inhibited $\mathrm{Al}$ electromigration or to "slow" the loss of $\mathrm{Cu}$ and hence increase electromigration resistance. To that end, and as one of the last efforts associated with this LDRD, we initiated and carried out experimental observations on the

MRS Symp Proc. April 1995 San Francisco CA 391 p385-390 characteristics of $\mathrm{Au}, \mathrm{Cu}, \mathrm{Ni}, \mathrm{Pd}$, and $\mathrm{Ag}$ in $\mathrm{Al}$ and $\mathrm{Al}-\mathrm{Cu}$ lines using the thin film cross-strip technique. As a preliminary consequence of these exploratory experiments we observed several interesting and not fully understood behaviors. The most intriguing was the counter-current flow of $\mathrm{Au}$ in $\mathrm{Al}$. We feel that this is a result of a vacancy flow effect which enhances $\mathrm{Al}$ electromigration while the $\mathrm{Au}$ is then "forced" to migrate towards the cathode end of the line. The ternary experiments were the most interesting from a technical point of view. Some ternary additions appear to slow $\mathrm{Cu}$ migration in $\mathrm{Al}-\mathrm{Cu}$ without leading to a significant increase in line resistance. If this is supported in the future by normal electromigration studies to failure we could have a new alloy system that would extend existing metallization technology for one or two generations further than has been expected. Although $\mathrm{Cu}$ interconnects are likely to become a necessity, their insertion into micro-electronics technology comes at significant risk both in regards to reliability and manufacturability. The extension of existing metallization methods could provide the critical time necessary to validate more radical solutions to the electromigration dilemma, one of the key barriers to continuing technological growth in electronics integration! 